\title{
Prospects for Manipulation of Mesenchymal Stem Cells in Tumor Therapy: Anti-Angiogenesis Property on the Spotlight
}

\author{
Marzieh Ghollasi ${ }^{1, *}$, Shahram Ghasembaglou ${ }^{2, *}$, Dariush Rahban ${ }^{3}$, Mohsen Korani ${ }^{4}$, \\ Morteza Motallebnezhad ${ }^{5}$, Milad Asadi ${ }^{6,7}$, Habib Zarredar ${ }^{2}$, Ali Salimi ${ }^{8}$ \\ ${ }^{I}$ Department of Cell and Molecular Biology, Faculty of Biological Science, Kharazmi University, Tehran, Iran \\ ${ }^{2}$ Tuberculosis and Lung Disease Research Center, Tabriz University of Medical Science, Tabriz, Iran \\ ${ }^{3}$ Department of Nanomedicine, School of Advanced Medical Technologies, Tehran University of Medical Sciences, Tehran, Iran \\ ${ }^{4}$ Chemical Injuries Research Center, Systems Biology and Poisonings Institute, Baqiyatallah University of Medical Sciences, Tehran, Iran \\ ${ }^{5}$ Department of Immunology, Faculty of Medicine, Iran University of Medical Sciences, Tehran, Iran \\ ${ }^{6}$ Immunology Research Center, Tabriz University of Medical Sciences, Tabriz, Iran \\ ${ }^{7}$ Department of Basic Oncology, Ege University, Institute of Health Sciences, Izmir, Turkey \\ ${ }^{8}$ Nanobiotechnology Research Center, Baqiyatallah University of Medical Sciences, Tehran, Iran
}

The interactions between the tumor microenvironment and the tumor cells confers a condition that accelerate or decelerate the development of tumor. Of these cells, mesenchymal stem cells (MSCs) have the potential to modulate the tumor cells. MSCs have been established with double functions, whereby contribute to a tumorigenic or anti-tumor setting. Clinical studies have indicated the potential of MSCs to be used as tool in treating the human cancer cells. One of the advantageous features of MSCs that make them as a well-suited tool for cancer therapy is the natural tumor-trophic migration potential. A key specification of the tumor development has been stablished to be angiogenesis. As a result, manipulation of angiogenesis has become an attractive approach for cancer therapy. This review article will seek to clarify the anti-angiogenesis strategy in modulating the MSCs to treat the tumor cells.

Keywords: Mesenchymal stem cells, Angiogenesis, Cancer therapy, Tumor microenvironment

Received: September 16, 2020, Revised: June 1, 2021,

Accepted: June 16, 2021, Published online: August 31, 2021

Correspondence to Ali Salimi

Nanobiotechnology Research Center, Baqiyatallah University of Medical Sciences, Azam Alley, Tehran 54714-25144, Iran

Tel: +98-21-88224578, Fax: +98-21-88224578

E-mail: salimiali@bmsu.ac.ir

Co-Correspondence to Habib Zarredar

Tuberculosis and Lung Disease Research Center, Tabriz University of Medical Science, Daneshghah St., Tabriz 28148-87321, Iran

Tel: +98-939-9431438, Fax: +98-413-3371440

E-mail: h.zarredar@tbzmed.ac.ir

*These authors contributed equally as co-first authors.

(a) This is an open-access article distributed under the terms of the Creative Commons Attribution Non-Commercial License (http://creativecommons.org/ licenses/by-nc/4.0/), which permits unrestricted non-commercial use, distribution, and reproduction in any medium, provided the original work is properly cited.

Copyright (c) 2021 by the Korean Society for Stem Cell Research

\section{Introduction}

Malignancies and cancer diseases account for a quarter of human death cases (1). The typical therapeutics for chances, including surgery, chemotherapy, and radiotherapy have not been able to be satisfying in treating the cancer patients. Although the methods for treating the malignancies and curing the cancer patients have greatly been improved in last years, in most of the cases there is not a proper response to the traditional therapeutics by the cancer cells. The tumor specificity is regarded to be the most important factor in limiting the efficacy of traditional cancer medications. Hence, it seems necessary for the medicine to search for the most efficient treatment approaches specifically targeting malignancies (2).

Mesenchymal stem cells (MSCs) are considered as the 
primary option for obtaining the stem cells for using in clinical and experimental applications. These cells have been obtained from various tissues, including brain, heart, and kidney suggesting a potential of promising candidates for several human diseases (3-7). MSCs are able to differentiate toward different cells and can simply be expanded in vitro, and therefore, have attracted the interests for utilizing in treatment options of that human diseases. They have the ability for self-renewal into mesenchymal lineages. MSCs exhibit pathotropic migratory features, establish them as potential candidates for selective delivering the drugs with the aim of tumor therapy $(3,4)$.

Tumor cells applies angiogenesis to be survived and proliferated (8). A number of growth factors and extracellular matrix proteins are responsible for tumor angiogenesis and, therefore, researchers have been attracted to utilize the targeted anti-angiogenic therapy of treatment of tumors $(9,10)$. Besides, several stem cells have been modified in vitro for expressing anti-angiogenic factors more efficiently (3). In this review article, we try to clarify the possible applications of MSCs through anti-angiogenic properties to treat cancer patients.

\section{Characteristics of MSCs}

MSCs are considered as the adult stem cells and naturally generated in the human body. MSCs were initially found in the bone marrow (BM) stromal matrix but they are distributed throughout the body $(11,12)$. MSCs are commonly found in several fetal and adult organs, like amniotic fluid, heart, skeletal muscle, adipose tissue, synovial tissue, placenta, pancreas. According to evidence, organs and tissues containing connective tissue have also MSCs in themselves (13). MSCs are considered as the primitive cells that are basically originating from the mesodermal germ layer and have been regarded as progenitor cells that have the potential to be developed to the connective tissues, skeletal muscle and vascular cells. MSCs have also the potential to be differentiated into cells of the mesodermal lineage, like fat, bone, and cartilage cells, but they can also differentiate into neuroectodermic and endodermic cells (14). MSCs have been considered as an important source in biomedicine due to the multilineage capacity (15). Because of an ease in acquisition, fast proliferative capacity, and the autologous transplantation potential, MSCs have been regarded as the first option of stem cells to be utilized in the regenerative medicine. MSCs may confer advantageous capacity for cell recovery in the harmed tissues (16). These stem cells has been reported to be involved in the modulation of immune cells and, hence, are attributed to be contributing factor in autoimmune disorders $(17,18)$. Studies have established a tumor specific migration and residence feature for MSCs, suggesting a positive capacity of these cells to be utilized as promising carriers of drugs for the aim of cancer therapy (19). Both pro- and anti-cancer characteristics have been attributed to MSCs (20); nonetheless, if MSCs are monitored efficiently, for example with anticancer agents, they could be applied in cancer therapy.

\section{Sources of MSCs}

Several sources of adult tissues have been identified for MSCs extraction and the harvesting of MSCs is not subject to the ethical issues (3). MSCs are potentially able to develop to various tissue types that might be either within or across the germ lines (21). BM-derived MSCs have been attributed with the highest level of lineage plasticity, that can be differentiated to the almost all cell types $(22,23)$. That notwithstanding, the available data obtained from the preclinical studies have indicated that the BM-derived MSC may not be the best source for utilization in the clinic. Invasive procedures are used for the harvesting of BM that yields a little number of cells. On the other side, the number, differentiation capacity, and life time of $\mathrm{BM}$-derived MSC are decreased as the individuals become older $(24,25)$. Adipose tissue and umbilical cord blood are considered as two alternative sources to harvest MSCs. Recently, MSCs obtained from adipose tissue have gained high attention to be used in preclinical and clinical evaluations, since tissue sampling is simple, the initial cell numbers is high, and the proliferation potential is satisfactory (26). However, phenotypes of MSCs, and the expansion and differentiation capacity of these cells originating from the adipose tissue are similar to those obtained from BM (27).

Furthermore, the umbilical cord blood as well as the wharton's jelly have been implied to have a plenty of MSCs (28). The cells extracted from placenta in adherent layer, which is considered a noninvasive and simple approach, have been reported to have a fibroblastiod morphology, which represent similar surface molecules as BM-derived MSCs, such as CD90, CD13, CD49e, CD29, and CD54 (29). Umbilical cord blood-derived MSCs show the ability to proliferate at a higher rate in comparison to the BM and adipose tissue-derived MSCs (27, 30), which is probably because of high telomerase activity in the umbilical cord blood-derived MSCs (31). 


\section{Circulation and Homing of MSCs}

As the first step in the homing, MSC needs to migrate from the $\mathrm{BM}$ to the circulation and move toward other tissues (Fig. 1). It has been indicated that MSCs can mobilize from the $\mathrm{BM}$ as well as other tissues to the circulation upon the various injury situations, including hypoxia, normoxia, and inflammation $(32,33)$. It is not completely divulged that how MSCs migrate from the BM and cross through the endothelium and how home in the tissues. That notwithstanding, it is clear that a common role of MSCs is to home in and repair the injured organs. The wound healing ability of MSCs initiates with their migration to the signals released from the injured organs (34). Various inflammatory factors released from wounds have also been identified in the tumor microenvironment that have been attributed to the migration of MSCs (35). Among the mediators/receptors involved in the migration of MSCs are MCP-1/CCR2, SDF-1/CXCR4, HGF/c- Met, SCF-c-Kit, VEGF/VEGFR, PDGF/PDGFR, and HMGB1/ RAGE (36). The involvement of the stromal cell-derived factor SDF-1 and the related receptor, CXC chemokine receptor-4 (CXCR4), in the migration of MSCs identified in surveys that either the receptor or the cytokine was knocked down (37-39). Furthermore, it was demonstrated that inhibition of CXCR4 and SDF-1 in mice cause marked decrease in the migration of exogenous stem cells to target organs (37). It has also been indicated that the blockade of CXCR4 resulted in an impaired homing of endogenous MSC into tumor sites, development of MSCs into myofibroblasts, and reduced MSC survival (40). It has

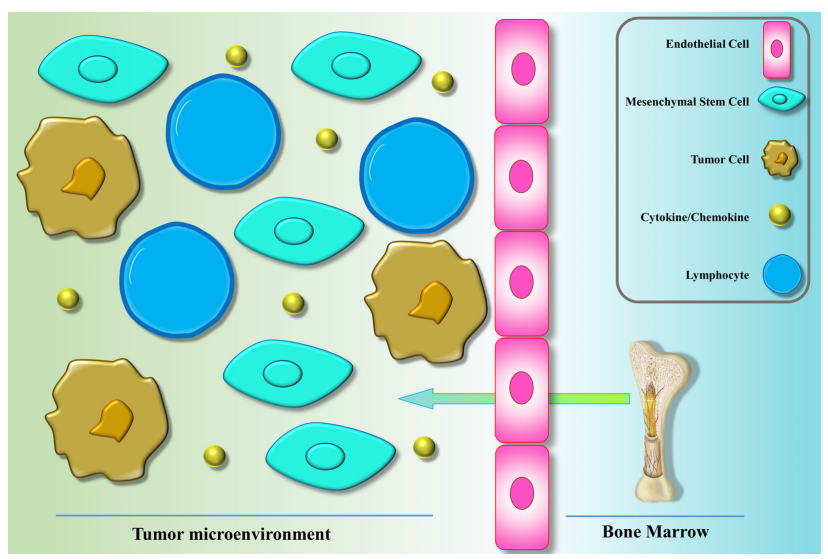

Fig. 1. The migration and homing of MSCs into the tumors. The inflammatory state conferred by the tumor microenvironment results in recruitment and homing of MSCs into tumor. After that, MSCs constitute the major cell type of the tumor microenvironment and play several functions. been revealed that chemokines like CXCL12, CXCL13, CXCL16, and their receptors play a role in the mutual mobilization of MSCs to BM and generate the BM niche. In the efficient homing of MSC into the BM, CXCL16 play an important role. CCL22 has been shown to play the strongest chemotactic impression in the migration of MSCs from the BM into the blood (41). Tumor tissues represent CCL2 and CXCL16, suggesting that they are playing a vital role in the mobilization and migration of MSCs into tumor sites (42-44).

Matrix metalloproteinase (MMPs) enzymes poses proteinases function, which is needed for proteolytical cleavage of precursor proteins, such as adhesion molecules, growth factors, cytokines, as well as some receptors. It has been demonstrated that MMP-1 and tissue inhibitor of metalloproteinase-3 (TIMP3) play role in the migration of MSCs across the BM endothelium (45). Plus, increased MMP-2 levels in the serum was attributed to the Clq complement -mediated migration of umbilical cord blood-derived MSC into the wounded tissue (46).

It was demonstrated that MSCs were recruited to the regions of irradiation, and local irradiation may increase the MSC specificity to be homed in particular tissues (47). These observations about the migratory characteristics of MSCs testify the promising potentials for designing the therapeutic tools that exploit the tumoritropic features of MSCs through engineering these cells towards potent cells via delivering the compounds against tumors.

\section{The Behavior of MSCs in the Tumor Microenvironment}

MSCs show different kinds of activities in various microenvironments because of the diversity in the signaling pathways involved in the stimulation of MSCs. In the clinical studies, employed MSCs are primarily naïve, obtained from normal tissues, and are usually harvested in vitro. Such naive MSCs have the ability to interfere with the tumor cell growth in co-cultures with tumor cells. It was observed that naive MSCs could decrease the expansion of leukemia cells. Such blocking property of naïve MSCs was seen to be dose-dependent, as the naive MSCs was increased, the rate of inhibition of tumor growth was increased. It was suggested that naive MSCs might decrease the expansion of tumor cells through mediators released from MSCs, such as Dickkopf-related protein 1 (DKK1), an inhibitor of Wnt signaling pathway in tumor cells (48). Interfering in the Wnt pathway was associated with the decreased expression of Cyclin D2 and c-Myc as well as increased expression of P27KIP1 and P21CIP1, 
that culminated in the interruption of tumor cell cycle (49-52). On the other side, naïve MSCs have the potential to activate the apoptosis in tumor cells (53) via increasing the expression of caspase 3 (50). Furthermore, naive MSCs have the potential to decrease the expansion of tumor cells via inhibiting the angiogenesis. In this way, naïve MSCs increase the apoptosis rate in vascular endothelial cells and interfere with angiogenesis $(54,55)$.

On the other side, tumor supporting activities of MSCs have also been reported (56). An equilibrium between anti-inflammatory and pro-inflammatory phenotypes of MSCs determine the influence of MSCs on the progression or suppression of tumor cells (57). It has been shown that MSCs inside tumors might undergo functional modulations to alter from an anti-tumorigenic phenotype to pro-tumorigenic MSC $(58,59)$. MSCs with anti-inflammatory properties are involved in contributing to tumor development by several mechanisms. Tumor perturbations has been shown to be associated with recruitment of MSCs to tumor sites (60). MSCs are able to regress immune responses against tumor cells (61), induce angiogenesis in tumors $(62,63)$, promote epithelial-to-mesenchymal transition (EMT) resulting in metastasis $(64,65)$, and induce a resistance in tumor cells to different therapeutics (66). Furthermore, it has been indicated that MSCs promote tumor progression through modulating the metabolic settings of tumor cells. Particularly, prostaglandin E2 secreted by MSCs is able to abrogate the apoptosis of lymphoblastic leukemic cells (67). MSCs produce lactate in a tumor microenvironment with high oxidative stress conditions that is uptaken via tumor cells, resulting in promoted migratory ability of tumor cells (68). Naïve MSCs have also been attributed with the increased angiogenesis in the colon cancer cell lines $(69,70)$, differentiation of MSCs to vascular endothelial cells in melanoma (71), increasing the development of cancer stem cells (CSCs) that promote the tumorigenesis and metastasis (72) in breast cancer (73), enhanced proliferation of gastric cancer cell lines $(72,74)$. Moreover, naïve MSCs might support tumor progression through increasing the migratory abilities of tumor cells via production of chemokines, like CXCR4 (75), CCL5 (76, 77), intercellular adhesion molecules (ICAMs), and vascular cell adhesion molecules (VCAMs) (78). Moreover, by suppressing the immune responses, MSCs has been observed to enhance the tumor development (79).

In addition, MSCs generate a wide range of chemokines, cytokines, and growth factors that mediate paracrine- or autocrine functions in the tumor development (80). These factors are able to modulate the tumor microenvironment to a tumor supporting settings. Several inflammatory mediators secreted by MSCs, including CXCL1, CXCL2 or CXCL12, are able to indirectly enhance tumor development in several tumor models $(81,82)$. In the same way, MSCs-derived inflammatory chemokines and cytokines, such as IL-8 and IL-6, contribute the tumor development in colon cancer (83) and breast cancer (73) models. By a paracrine mechanism via IL-6 and CXCL7 secretion, MSCs was shown to migrate into breast cancer xenografts and promoted the development of CSC subpopulations (73).

It seems that MSCs may represent bidirectional behaviors on tumor development, and various studies have reported a disagreement on the MSCs effect on the tumor progression or inhibition. However, it is worthy to mention that there is a general agreement that MSCs are frequently contribute to the tumor development in comparison to suppressing tumor growth, which is widely attributed to the regenerative functions and immune system suppression by MSCs (84, 85).

\section{MSC-Derived Extracellular Vesicles}

Extracellular Vesicles (EVs), like exosomes, are membrane-enclosed vesicle with a size of $40 \sim 1,000 \mathrm{~nm}$ that are produced by several cells, such as MSCs (86). EVs primarily encompass microRNAs (miRNAs) as well as proteins, which is encapsulated by a lipid bilayer membrane (87-90). Secreted EVs are able to move toward other cells and bind them in order to deliver several signals to the targets (91). MSC-derived EVs are able to modulate several processes in the tumor cells, including metastasis, angiogenesis, and proliferation (92) as well as control immune cells $(93,94)$. Indeed, MSC-derived EVs might promote the tumor development or repress tumor progression (95).

Umbilical cord derived MSC-EVs was shown to meliorate the oxidative stress and cell apoptosis as well as promote cell proliferation in rats with cisplatin-induced nephrotoxicity (96). Additionally, Zhu et al. (97) indicated that MSC-derived EVs promoted tumor growth through promoting the expression of vascular endothelial growth factor (VEGF) in tumor cells by induction of the extracellular signal-regulated kinasel/2 (ERK1/2) pathway. Therefore, MSCs are able to promote tumor growth and angiogenesis by secreting EVs.

On the other hand, it was shown that BM-derived MSCs-EV caused cell-cycle arrest in the G0/G1 phase and induced apoptosis in tumor cells (98). Additionally, MSCs-EV interrupted the angiogenesis by suppressing the 
expression of VEGF in tumor cells (99). Furthermore, MSC- derived EVs containing miRNAs targeting VEGF were observed to suppress angiogenesis in human nasopharyngeal carcinoma cells (100). miR-143, which has been investigated in several malignancies (101), was indicated to be harbored by MSC-derived EVs an reduced the migration of osteosarcoma cells (102). As a consequence, MSC-derived EVs are able to repress the tumor cell proliferation and angiogenesis.

\section{Exertion of MSCs for Treatment of Tumor}

Naïve MSCs (have not undergone any manipulation) have been reported to possess antitumor properties. This antitumor activity has been attributed to the mediators produced by MSC that have the potential to decrease the proliferation of tumor cells in different cancers, including breast adenocarcinoma, melanoma, hepatoma, lung cancer, and glioma $(52,103-105)$. In a mouse model of Kaposi's sarcoma, the BM-derived MSCs were administered intravenously that resulted in the homing of these cells in the tumor sites and prevented the progression of tumor (106). Studies in vitro and in the mouse model of melanoma indicated that MSCs possess the ability to repress the angiogenesis (55). Furthermore, MSC administration to the melanoma mice model subcutaneously eventuated in increased apoptosis rate and decreased expansion of tumor (55). In addition, umbilical cord blood-derived MSCs overexpressing CD44 and CD133 were reported to increase apoptosis rate in the glioblastoma multiforme cells in vitro (107). As well, umbilical cord blood-derived MSCs administration resulted in underexpression of XIAP activating caspase- 3 and caspase-9, leading to increased apoptosis rate in the glioma cells (108). To comply with these observations, umbilical cord blood-derived MSCs as well as MSCs from other sources indicated reduced expansion of the glioblastoma multiforme cells through tumor necrosis factor (TNF)-related apoptosis-inducing ligand (TRAIL) (109).

\section{Modulation of Angiogenesis for the Treatment of Cancer}

\section{The process of angiogenesis}

In the embryonic development period, neovascularization or new blood vessel formation from pre-existing vessels is regarded as a major occurrence that leads to the construction of vasculature system that contains endothelial cells (ECs) (110). During the physiological situations, vasculogenesis is seldomly observed in the adults. That not- withstanding, angiogenesis may be seen in adults as a physiological event during pregnancy as well as the cyclical growth of vessels in the ovarian corpus luteum (111, 112). In the pathological conditions, such as tissue repair during wound healing and tumor growth, neovascularization is considered as a normal phenomenon (113). However, it should be noted that the structure and composition of the tumor vessels are different from those occurred in the normal vessels. It has been shown that ECs of tumor tissues express higher levels of CD109, CD137, CD276, and placenta growth factor (PIGF) compared with the ECs originating from the normal non-tumor organs. In spite of a bulk of studies with respect to the cellular and molecular characteristics of ECs from different tumors, there are disagreements with respect to the origin of ECs in the tumor conditions (114). It has been reported that endothelial progenitor cells (EPCs) are actively involved in the angiogenesis process of tumors (114). However, it is clear that the initiation of angiogenesis requires a divergence toward a profile of increased angiogenesis activators, while inhibited process of angiogenesis suppression. The critical stimulating mediators of angiogenesis include vascular endothelial growth factor (VEGF)-A, fibroblast growth factor (FGF), and hepatocyte growth factor (HGF), PlGF, and MMPs $(115,116)$. Adversely, thrombospondins, endostatin, angiostatin, and interleukin (IL)-12 are important endogenous inhibitors of angiogenesis (117). Taken together, angiogenesis is thought to be involved in the progression and development of tumors.

\section{Anti-angiogenesis tumor therapy via interfering with VEGF pathway}

Noting to the participation of the angiogenesis process in the development of tumors, it seems that the molecules involved in the tumor angiogenesis can be targeted as a therapeutic strategy. Inhibition or blocking of the growth factors or signaling pathways prerequisite for the development and progression of ECs is regarded as a logical mindset for prevention of tumor vasculogenesis and, therefore, tumor repression $(113,118,119)$. VEGF is considered as an critical angiogenetic factor which is involved in both physiological and pathological situations (120). Genetic alterations in the $V E G F$ gene have been reported to cause defects in the normal development angiogenesis and death in the embryonic period (120). Hypoxia inducible factor (HIF)- $1 \alpha$, through binding to the VEGF promoter, regulates the expression of VEGF (121). A hypoxic condition in various regions of tumors results in the increased expression of VEGF in tumor niche, leading to an enhanced 
blood supply and expedited expansion of tumor cells (122). Furthermore, VEGF is normally overexpressed in the microenvironment of numerous human tumors (123); however, VEGF receptors of VEGFR1, VEGFR2, and VEGFR3 have been shown to be highly expressed in the tumor associated ECs (124, 125).

The tumor mice model were administered with an monoclonal antibody targeting the VEGF that manifested as a remarkable deceleration in the tumor growth (126). Bevacizumab is a humanized monoclonal antibody to neutralize VEGF (127), was the first anti-angiogenic monoclonal antibody approved by the FDA (Food \& Drug Administration) in 2003 for the therapy of metastatic colorectal cancer patients $(128,129)$. In addition, the promising effects of bevacizumab in treating patients with non-small cell lung cancer (NSCLC) (130) and metastatic breast cancer (131) were established. Upon these successful experiences, some other factors inhibiting the VEGF pathway, target either VEGF or its receptor, have been under clinical trial studies. As a soluble receptor of VEGF, VEGF-TrapR1R2, which carries the functional parts of the VEGFR1 and VEGFR2 (132), has been shown to have the ability to neutralize the circulating VEGF and be utilized in tumor therapy. In addition, it has been observed that VEGF-TrapR1R2 possesses better anti-tumor effects in relation to DC101, which is a VEGF receptor blocker. Studies have shown that the inhibition of VEGF signaling pathway, through the components that blocks the VEGF receptor, are efficiently involved in the repression of the tumor progression $(133,134)$. Receptor tyrosine kinase inhibitors (RTKIs), which targets molecules in the VEGF signaling pathways, including linifanib (135, 136), cabozantinib (137), axitinib (138), tivozatinib (139), vendatanib (140), sunitinib (141), pazopanib (142), and sorafenib (143) has been shown to be promising in the treatment of various tumors. In spite of promising effects of these therapeutics in the clinical trials, the detailed mechanisms underlying their beneficial anti-angiogenic effects have not fully been disclosed. Preclinical models have revealed that the inhibition of angiogenesis has been the main mechanism of angiogenesis inhibitors that target VEGF pathway. That notwithstanding, vascular normalization has also been implicated as another mechanism of anti-angiogenetic agents. This mechanism imply to the targeting of the non-functional vessels in tumors, that implement positive functions through decreased blood flow to the tumor, or efficient drug delivery to the tumor cells (144). Therefore, progression in designing agents with potential targeting of VEGF pathway and, therefore suppressing the angiogenesis, provided prosperous ther- apeutic strategy for tumors that have the potential to be further improved in combination with other tools and approaches.

Vascular disrupting agents (VDAs) have been considered as another class of anti-angiogenetic compounds above and beyond the VEGF inhibitors. To implement their anti-angiogenic functions to prevent tumor development, VDAs cause vascular collapse, manifesting as hypoxia, which in turn cause tumor necrosis (145). ASA404 is a VDA that has been shown to cause apoptosis in the ECs, and, thereupon, diminished blood flow to the tumor cells. Clinical studies is currently assessing the efficacy of ASA404 in the NSCLC patients (146).

\section{MSCs and Anti-Angiogenic Cancer Therapy}

Angiogenesis is applied by tumors to proceed the process of growth (8). Angiogenesis can be inhibited through the exertion of MSCs as vehicles to deliver anti-angiogenetic drugs to the tumors and, therefore, limit the tumor progression. Such engendered MSCs have displayed a tropism to cancer organs and can deliver anti-angiogenic drugs to the tumor sites, while having little adverse effects (147). However, it should be noted that a systemic supply of anti- angiogenic drugs for a long time may present with adverse effects, such as drug toxicity, as well as decreased blood supply of the tissues, which in turn results in the poor delivery of chemotherapeutic drugs to the target sites (148).

Dysregulated balance of pro-angiogenic and anti-angiogenic mediators as well as growth factors in the tumor microenvironment has been attributed to the tumor-mediated angiogenesis $(9,149)$. As an endogenous inhibitor of angiogenesis in the tumors, endostatin has been exerted as an important anti-angiogenic agent in several malignancies (150). In a study, the human placenta-derived MSCs were manipulated to deliver endostatin and were injected into nude mice. These MSCs, which expressed endostatin, were observed to be resided in the tumor site and a significant reduction in the tumor size was reported without considerable systemic toxicity and adverse effects. The reduced tumor size was reported to be due to increased apoptosis in the tumor cells and blocked angiogenesis (150). Furthermore, a phase II clinical trial reported that delivery of anti-angiogenic compounds resulted in the correction of the abnormal structure and malfunction of the blood vessels, culminating in a remarkable decrease in the brain edema (151). This correction in the vessel structure was reported to be due to decreased vessel diameter and permeability $(152,153)$. Intratumoral 
administration of MSCs has been shown to be accompanied with the residence of these cells in the tumor sites and interfering with vasculogenesis, implying to a beneficial potential of MSCs for targeted anti-angiogenic drug delivery (154). The genetically-modified human adipose-derived MSCs expressing the interferon $\gamma$-induced protein $10 \mathrm{kDa}$ (IP-10), which is a powerful chemoattractant, in a mouse model of metastatic melanoma resulted in inhibited tumor cell growth and limited angiogenesis and significantly associated with increased survival of mice (155).

\section{The Road ahead toward the Delivery of Anti-Angiogenic Inhibitors via MSCs}

Estrogen, a female sex hormone, has been shown to stimulate angiogenesis through acting directly on ECs, as well as indirectly on endometrial cells. It has also been reported that estrogen triggers the expression of VEGF in the uterine stromal cells $(156,157)$. ER has been established as a potential target of various drugs for inhibition of the breast cancer progression (158). The ligation of estrogen to the estrogen receptor (ER) causes an increased proliferation; thereupon, endocrine cancer therapy attempts to prevent the binding of estrogen to the ER and block the aftermath signaling. Tamoxifen and raloxifene are considered as selective estrogen receptor modulators (SERMs) that are competitive inhibitors of estrogen and directly bind to ER. Interfering with the estrogen pathway has been indicated as an efficient strategy for the therapy of hormone responsive breast cancers, while conferring little toxic side effects (159). High expression of ER $\beta$ has been observed in the prostate (160). Implying to the possible response of prostate cancer to SERMs (161). Moreover, promising outcomes have been established about the estrogen therapy in the ovarian cancer patients (162). As well, the Women's Health Initiative (WHI) trial indicated that estrogen is involved in the colon carcinogenesis (163). As a result, with respect to the role of estrogen and ERs in the process of angiogenesis and the promising outcomes of estrogen/ER pathway blockade, it seems that MSCs can be exerted as machine for the targeted delivery of drugs that interfere with this pathway. Moreover, monoclonal antibodies targeting ERs can be evaluated to inhibit angiogenesis in the tumor microenvironment. SERMs have been attributed with a number of adverse effects in the tissues that are not the target of such compounds. Hence, strategies for targeting the estrogen/ER pathways needs to be optimized to obtain best results. This is a hypothesis by the authors, requiring studies in the animal models as well as clinical trials to be validated.

It has been demonstrated that progesterone prevents the proliferation of ECs in vitro and interferes with the cell cycle in the human dermal endothelial cells (164). Progesterone receptor is expressed on the endometrial ECs and may play a role in the suppression of VEGF-induced proliferation of ECs (165). Therefore, targeting the progesterone pathway through manipulated MSCs seems potential therapeutic strategy for cancer treatment, a hypothesis that needs to be extensively studied.

The corpus luteum is considered as a temporary endocrine tissue in ovaries that are involved in the prosperous gestation of mammals. When a follicle undergone the rupture process upon ovulation, the corpus luteum is then converted to debris and undergoes a number of modifications, such as differentiation and growth, which rely on the angiogenesis process. It has been reported that some endogenous stimulatory and inhibitory compounds exist in the corpus luteum to regulate the angiogenesis (166). Follicular cells of ovaries produce the pigment epithelium-derived factor (PEDF), which is a physiological inhibitor of angiogenesis (167). PEDF possess an anti-angiogenic function in the corpus luteum, implying to its possible utility as an anti-angiogenesis therapy of cancer in the future, probably through delivering via MSCs as vehicles.

\section{Challenges in Application of MSC in Cancer Therapy}

The therapeutic application of MSCs has been associated with multiple challenges that may limit the clinical efficacy of this approach. Among the drawbacks in exertion of MSCs are inappropriate homing of MSCs in the body and little accumulation of these cells in the target tumor (168). Additionally, MSCs may lose their therapeutic potential, gain immunogenicity properties, and obtain tumorigenic characteristics during physiological differentiation into mesenchymal lineages (169). It has also been shown that endogenous MSCs are able to produce several mediators and activate signaling pathways to promote the angiogenesis in tumor cells, like colorectal cancer (69) and melanoma (170). However, a study analyzed clinical 36 trials that used BM-derived MSCs through intravascular delivery in different subjects, including graft versus host disease, Crohn's disease, ischemic stroke, cardiomyopathy, myocardial infarction, and healthy volunteers. This study indicated no associationship between the MSCs therapy and tumorigenic risk. Moreover, no severe adverse effects of the MSC therapy were observed (171). Most of 
the clinical trials have evaluated the safety and tolerability of the MSC therapy in cancers. Nonetheless, the adverse effects of MSC therapy in promotion of tumor, instead of suppressing it, has little been studied. The tumorigenic evaluation of MSC therapy needs long time follow-up of the patients, as carcinogenesis is a gradual process.

\section{Concluding Remarks}

Several beneficial properties have been proposed for MSCs that make them appropriate candidates for cell-based therapeutic tool in cancer therapy. First, MSCs are able to mobilize and preferentially home in tumor tissues and interact with various cells present in tumor microenvironment. Furthermore, MSCs are easily available, have no or little immunogenic features, can be simply manipulated in vitro. Little have been surveyed with respect to the preclinical evaluation of the MSC potential to be exerted as vehicles to locally deliver/express a single therapeutic compound in cancers. Despite a promising experience in the promoted survival of cancer cases through anti-angiogenic therapy, the pooled findings testify a limited overall survival improvement $(172,173)$. These limitations stem from several issues. First, tumor microenvironment may exert mechanisms to resist against anti-angiogenetic molecules and, therefore, limit the efficacy of such therapeutics (174). Second, anti-angiogenetic drugs may develop vascular collapse that may result in a hypoxic state, which in turn may result in radio-resistance, chemo-resistance and anti-angiogenesis resistance $(175,176)$. These adverse effects may culminate in tumor metastasis and, therefore, negatively impress the clinical exertion of anti-angiogenic drugs. In spite of an improvement in our knowledge of MSCs in recent years, little has been attempted with respect to the employment of these cells to downmodulate the angiogenesis in the clinics. Therefore, filling this gape requires developing state-of-the- art technologies and new concepts in exertion of anti-angiogenic compounds conferring little side effects. To attain this end, engineering MSCs to specifically deliver the angiogenesis inhibitors could be still promising, particularly when combined with other therapeutics and targeting other pathways simultaneously. As well, searching for novel molecular targets to diminish the angiogenesis could be a part of answer to this gap.

\section{Acknowledgments}

Not applicable.

\section{Potential Conflict of Interest}

The authors have no conflicting financial interest.

\section{Author Contributions}

MG and ShGh; Developed the main idea, participated in manuscript drafting, and read the manuscript critically. DR; Developed the main idea, participated in manuscript drafting, and read the manuscript critically. MK and MA; Developed the main idea, participated in manuscript drafting, and read the manuscript critically. MM; Draw the figure, participated in manuscript drafting, and read the manuscript critically. AS and HZ; Developed the main idea, participated in manuscript drafting, and read the manuscript critically.

\section{References}

1. Siegel RL, Miller KD, Jemal A. Cancer statistics, 2016. CA Cancer J Clin 2016;66:7-30

2. Sawyers C. Targeted cancer therapy. Nature 2004;432:294297

3. Corsten MF, Shah K. Therapeutic stem-cells for cancer treatment: hopes and hurdles in tactical warfare. Lancet Oncol 2008;9:376-384

4. Teo AK, Vallier L. Emerging use of stem cells in regenerative medicine. Biochem J 2010;428:11-23

5. Fathollahi A, Gabalou NB, Aslani S. Mesenchymal stem cell transplantation in systemic lupus erythematous, a mesenchymal stem cell disorder. Lupus 2018;27:1053-1064

6. Zanganeh E, Soudi S, Zavaran Hosseini A, Khosrojerdi A. Repeated intravenous injection of adipose tissue derived mesenchymal stem cells enhances Th1 immune responses in Leishmania major-infected $\mathrm{BALB} / \mathrm{c}$ mice. Immunol Lett 2019;216:97-105

7. Khosrojerdi A, Soudi S, Hosseini AZ, Eshghi F, Shafiee A, Hashemi SM. Immunomodulatory and therapeutic effects of mesenchymal stem cells on organ dysfunction in sepsis. Shock 2021;55:423-440

8. Jain RK, di Tomaso E, Duda DG, Loeffler JS, Sorensen AG, Batchelor TT. Angiogenesis in brain tumours. Nat Rev Neurosci 2007;8:610-622

9. Samant RS, Shevde LA. Recent advances in anti-angiogenic therapy of cancer. Oncotarget 2011;2:122-134

10. Javan MR, Khosrojerdi A, Moazzeni SM. New insights into implementation of mesenchymal stem cells in cancer therapy: prospects for anti-angiogenesis treatment. Front Oncol 2019;9:840

11. Friedenstein AJ, Piatetzky-Shapiro II, Petrakova KV. Osteogenesis in transplants of bone marrow cells. J Embryol Exp Morphol 1966;16:381-390

12. Friedenstein AJ, Petrakova KV, Kurolesova AI, Frolova GP. Heterotopic of bone marrow. Analysis of precursor cells for osteogenic and hematopoietic tissues. Transplantation 1968;6:230-247 
13. Väänänen HK. Mesenchymal stem cells. Ann Med 2005; 37:469-479

14. Uccelli A, Moretta L, Pistoia V. Mesenchymal stem cells in health and disease. Nat Rev Immunol 2008;8:726-736

15. Pittenger MF, Mackay AM, Beck SC, Jaiswal RK, Douglas R, Mosca JD, Moorman MA, Simonetti DW, Craig S, Marshak DR. Multilineage potential of adult human mesenchymal stem cells. Science 1999;284:143-147

16. Le Blanc K, Pittenger M. Mesenchymal stem cells: progress toward promise. Cytotherapy 2005;7:36-45

17. Fiorina P, Jurewicz M, Augello A, Vergani A, Dada S, La Rosa S, Selig M, Godwin J, Law K, Placidi C, Smith RN, Capella C, Rodig S, Adra CN, Atkinson M, Sayegh MH, Abdi R. Immunomodulatory function of bone marrow-derived mesenchymal stem cells in experimental autoimmune type 1 diabetes. J Immunol 2009;183:993-1004

18. Nauta AJ, Fibbe WE. Immunomodulatory properties of mesenchymal stromal cells. Blood 2007;110:3499-3506

19. Loebinger MR, Janes SM. Stem cells as vectors for antitumour therapy. Thorax 2010;65:362-369

20. Mishra PJ, Mishra PJ, Glod JW, Banerjee D. Mesenchymal stem cells: flip side of the coin. Cancer Res 2009;69:12551258

21. Anderson DJ, Gage FH, Weissman IL. Can stem cells cross lineage boundaries? Nat Med 2001;7:393-395

22. Jiang Y, Jahagirdar BN, Reinhardt RL, Schwartz RE, Keene CD, Ortiz-Gonzalez XR, Reyes M, Lenvik T, Lund T, Blackstad M, Du J, Aldrich S, Lisberg A, Low WC, Largaespada DA, Verfaillie CM. Pluripotency of mesenchymal stem cells derived from adult marrow. Nature 2002;418:41-49

23. Orlic D, Kajstura J, Chimenti S, Jakoniuk I, Anderson SM, Li B, Pickel J, McKay R, Nadal-Ginard B, Bodine DM, Leri A, Anversa P. Bone marrow cells regenerate infarcted myocardium. Nature 2001;410:701-705

24. Bentzon JF, Stenderup K, Hansen FD, Schroder HD, Abdallah BM, Jensen TG, Kassem M. Tissue distribution and engraftment of human mesenchymal stem cells immortalized by human telomerase reverse transcriptase gene. Biochem Biophys Res Commun 2005;330:633-640

25. Mueller SM, Glowacki J. Age-related decline in the osteogenic potential of human bone marrow cells cultured in three-dimensional collagen sponges. J Cell Biochem 2001; 82:583-590

26. Stewart MC, Stewart AA. Mesenchymal stem cells: characteristics, sources, and mechanisms of action. Vet Clin North Am Equine Pract 2011;27:243-261

27. Kern S, Eichler H, Stoeve J, Klüter H, Bieback K. Comparative analysis of mesenchymal stem cells from bone marrow, umbilical cord blood, or adipose tissue. Stem Cells 2006;24:1294-1301

28. Prindull G, Ben-Ishay Z, Ebell W, Bergholz M, Dirk T, Prindull B. CFU-F circulating in cord blood. Blut 1987; 54:351-359

29. Erices A, Conget P, Minguell JJ. Mesenchymal progenitor cells in human umbilical cord blood. Br J Haematol 2000;
109:235-242

30. Goodwin HS, Bicknese AR, Chien SN, Bogucki BD, Quinn CO, Wall DA. Multilineage differentiation activity by cells isolated from umbilical cord blood: expression of bone, fat, and neural markers. Biol Blood Marrow Transplant 2001;7:581-588

31. Chang YJ, Shih DT, Tseng CP, Hsieh TB, Lee DC, Hwang SM. Disparate mesenchyme-lineage tendencies in mesenchymal stem cells from human bone marrow and umbilical cord blood. Stem Cells 2006;24:679-685

32. He Q, Wan C, Li G. Concise review: multipotent mesenchymal stromal cells in blood. Stem Cells 2007;25:69-77

33. Hong HS, Lee J, Lee E, Kwon YS, Lee E, Ahn W, Jiang $\mathrm{MH}$, Kim JC, Son Y. A new role of substance P as an injury-inducible messenger for mobilization of CD29(+) stromal-like cells. Nat Med 2009;15:425-435

34. Spaeth EL, Kidd S, Marini FC. Tracking inflammationinduced mobilization of mesenchymal stem cells. Methods Mol Biol 2012;904:173-190

35. Spaeth E, Klopp A, Dembinski J, Andreeff M, Marini F. Inflammation and tumor microenvironments: defining the migratory itinerary of mesenchymal stem cells. Gene Ther 2008;15:730-738

36. Momin EN, Vela G, Zaidi HA, Quiñones-Hinojosa A. The oncogenic potential of mesenchymal stem cells in the treatment of cancer: directions for future research. Curr Immunol Rev 2010;6:137-148

37. Imitola J, Raddassi K, Park KI, Mueller FJ, Nieto M, Teng YD, Frenkel D, Li J, Sidman RL, Walsh CA, Snyder EY, Khoury SJ. Directed migration of neural stem cells to sites of CNS injury by the stromal cell-derived factor lalpha/CXC chemokine receptor 4 pathway. Proc Natl Acad Sci U S A 2004;101:18117-18122

38. Son BR, Marquez-Curtis LA, Kucia M, Wysoczynski M, Turner AR, Ratajczak J, Ratajczak MZ, Janowska-Wieczorek A. Migration of bone marrow and cord blood mesenchymal stem cells in vitro is regulated by stromal-derived factor-1-CXCR4 and hepatocyte growth factor-c-met axes and involves matrix metalloproteinases. Stem Cells 2006; 24:1254-1264

39. Nakamizo A, Marini F, Amano T, Khan A, Studeny M, Gumin J, Chen J, Hentschel S, Vecil G, Dembinski J, Andreeff M, Lang FF. Human bone marrow-derived mesenchymal stem cells in the treatment of gliomas. Cancer Res 2005;65:3307-3318

40. Quante M, Tu SP, Tomita H, Gonda T, Wang SS, Takashi S, Baik GH, Shibata W, Diprete B, Betz KS, Friedman R, Varro A, Tycko B, Wang TC. Bone marrow-derived myofibroblasts contribute to the mesenchymal stem cell niche and promote tumor growth. Cancer Cell 2011;19:257272

41. Smith H, Whittall C, Weksler B, Middleton J. Chemokines stimulate bidirectional migration of human mesenchymal stem cells across bone marrow endothelial cells. Stem Cells Dev 2012;21:476-486

42. Darash-Yahana M, Gillespie JW, Hewitt SM, Chen YY, 
Maeda S, Stein I, Singh SP, Bedolla RB, Peled A, Troyer DA, Pikarsky E, Karin M, Farber JM. The chemokine CXCL16 and its receptor, CXCR6, as markers and promoters of inflammation-associated cancers. PLoS One 2009;4:e6695

43. Curiel TJ, Coukos G, Zou L, Alvarez X, Cheng P, Mottram P, Evdemon-Hogan M, Conejo-Garcia JR, Zhang L, Burow M, Zhu Y, Wei S, Kryczek I, Daniel B, Gordon A, Myers L, Lackner A, Disis ML, Knutson KL, Chen L, Zou W. Specific recruitment of regulatory T cells in ovarian carcinoma fosters immune privilege and predicts reduced survival. Nat Med 2004;10:942-949

44. Jacobs JF, Idema AJ, Bol KF, Grotenhuis JA, de Vries IJ, Wesseling P, Adema GJ. Prognostic significance and mechanism of Treg infiltration in human brain tumors. J Neuroimmunol 2010;225:195-199

45. De Becker A, Van Hummelen P, Bakkus M, Vande Broek I, De Wever J, De Waele M, Van Riet I. Migration of culture-expanded human mesenchymal stem cells through bone marrow endothelium is regulated by matrix metalloproteinase-2 and tissue inhibitor of metalloproteinase-3. Haematologica 2007;92:440-449

46. Qiu Y, Marquez-Curtis LA, Janowska-Wieczorek A. Mesenchymal stromal cells derived from umbilical cord blood migrate in response to complement Clq. Cytotherapy 2012;14:285-295

47. François S, Bensidhoum M, Mouiseddine M, Mazurier C, Allenet B, Semont A, Frick J, Saché A, Bouchet S, Thierry D, Gourmelon P, Gorin NC, Chapel A. Local irradiation not only induces homing of human mesenchymal stem cells at exposed sites but promotes their widespread engraftment to multiple organs: a study of their quantitative distribution after irradiation damage. Stem Cells 2006;24: 1020-1029

48. Ramasamy R, Lam EW, Soeiro I, Tisato V, Bonnet D, Dazzi F. Mesenchymal stem cells inhibit proliferation and apoptosis of tumor cells: impact on in vivo tumor growth. Leukemia 2007;21:304-310

49. Zhu Y, Sun Z, Han Q, Liao L, Wang J, Bian C, Li J, Yan X, Liu Y, Shao C, Zhao RC. Human mesenchymal stem cells inhibit cancer cell proliferation by secreting DKK-1. Leukemia 2009;23:925-933

50. Lu YR, Yuan Y, Wang XJ, Wei LL, Chen YN, Cong C, Li SF, Long D, Tan WD, Mao YQ, Zhang J, Li YP, Cheng JQ. The growth inhibitory effect of mesenchymal stem cells on tumor cells in vitro and in vivo. Cancer Biol Ther 2008;7:245-251

51. Qiao L, Xu ZL, Zhao TJ, Ye LH, Zhang XD. Dkk-1 secreted by mesenchymal stem cells inhibits growth of breast cancer cells via depression of Wnt signalling. Cancer Lett 2008;269:67-77

52. Qiao L, Xu Z, Zhao T, Zhao Z, Shi M, Zhao RC, Ye L, Zhang X. Suppression of tumorigenesis by human mesenchymal stem cells in a hepatoma model. Cell Res 2008;18: 500-507

53. Sun B, Roh KH, Park JR, Lee SR, Park SB, Jung JW,
Kang SK, Lee YS, Kang KS. Therapeutic potential of mesenchymal stromal cells in a mouse breast cancer metastasis model. Cytotherapy 2009;11:289-298

54. Secchiero P, Zorzet S, Tripodo C, Corallini F, Melloni E, Caruso L, Bosco R, Ingrao S, Zavan B, Zauli G. Human bone marrow mesenchymal stem cells display anti-cancer activity in SCID mice bearing disseminated non-Hodgkin's lymphoma xenografts. PLoS One 2010;5:e11140

55. Otsu K, Das S, Houser SD, Quadri SK, Bhattacharya S, Bhattacharya J. Concentration-dependent inhibition of angiogenesis by mesenchymal stem cells. Blood 2009;113: 4197-4205

56. Hanahan D, Weinberg RA. Hallmarks of cancer: the next generation. Cell 2011;144:646-674

57. Rhee KJ, Lee JI, Eom YW. Mesenchymal stem cell-mediated effects of tumor support or suppression. Int J Mol Sci 2015;16:30015-30033

58. Waterman RS, Tomchuck SL, Henkle SL, Betancourt AM. A new mesenchymal stem cell (MSC) paradigm: polarization into a pro-inflammatory MSC1 or an Immunosuppressive MSC2 phenotype. PLoS One 2010;5:e10088

59. Waterman RS, Henkle SL, Betancourt AM. Mesenchymal stem cell 1 (MSC1)-based therapy attenuates tumor growth whereas MSC2-treatment promotes tumor growth and metastasis. PLoS One 2012;7:e45590

60. Houthuijzen JM, Daenen LG, Roodhart JM, Voest EE. The role of mesenchymal stem cells in anti-cancer drug resistance and tumour progression. Br J Cancer 2012;106: 1901-1906

61. Poggi A, Giuliani M. Mesenchymal stromal cells can regulate the immune response in the tumor microenvironment. Vaccines (Basel) 2016;4:41

62. Li GC, Zhang HW, Zhao QC, Sun LI, Yang JJ, Hong L, Feng F, Cai L. Mesenchymal stem cells promote tumor angiogenesis via the action of transforming growth factor $\beta$ 1. Oncol Lett 2016;11:1089-1094

63. Zhang T, Lee YW, Rui YF, Cheng TY, Jiang XH, Li G. Bone marrow-derived mesenchymal stem cells promote growth and angiogenesis of breast and prostate tumors. Stem Cell Res Ther 2013;4:70

64. Fregni G, Quinodoz M, Möller E, Vuille J, Galland S, Fusco C, Martin P, Letovanec I, Provero P, Rivolta C, Riggi N, Stamenkovic I. Reciprocal modulation of mesenchymal stem cells and tumor cells promotes lung cancer metastasis. EBioMedicine 2018;29:128-145

65. Ridge SM, Sullivan FJ, Glynn SA. Mesenchymal stem cells: key players in cancer progression. Mol Cancer 2017; $16: 31$

66. Bergfeld SA, Blavier L, DeClerck YA. Bone marrow-derived mesenchymal stromal cells promote survival and drug resistance in tumor cells. Mol Cancer Ther 2014;13: 962-975

67. Naderi EH, Skah S, Ugland H, Myklebost O, Sandnes DL, Torgersen ML, Josefsen D, Ruud E, Naderi S, Blomhoff HK. Bone marrow stroma-derived PGE2 protects BCPALL cells from DNA damage-induced p53 accumulation 
and cell death. Mol Cancer 2015;14:14

68. Bonuccelli G, Avnet S, Grisendi G, Salerno M, Granchi D, Dominici M, Kusuzaki K, Baldini N. Role of mesenchymal stem cells in osteosarcoma and metabolic reprogramming of tumor cells. Oncotarget 2014;5:7575-7588

69. Huang WH, Chang MC, Tsai KS, Hung MC, Chen HL, Hung SC. Mesenchymal stem cells promote growth and angiogenesis of tumors in mice. Oncogene 2013;32:43434354

70. Lin G, Yang R, Banie L, Wang G, Ning H, Li LC, Lue TF, Lin CS. Effects of transplantation of adipose tissue-derived stem cells on prostate tumor. Prostate 2010;70: 1066-1073

71. Suzuki K, Sun R, Origuchi M, Kanehira M, Takahata T, Itoh J, Umezawa A, Kijima H, Fukuda S, Saijo Y. Mesenchymal stromal cells promote tumor growth through the enhancement of neovascularization. Mol Med 2011;17: 579-587

72. Li Z. CD133: a stem cell biomarker and beyond. Exp Hematol Oncol 2013;2:17

73. Liu S, Ginestier C, Ou SJ, Clouthier SG, Patel SH, Monville F, Korkaya H, Heath A, Dutcher J, Kleer CG, Jung Y, Dontu G, Taichman R, Wicha MS. Breast cancer stem cells are regulated by mesenchymal stem cells through cytokine networks. Cancer Res 2011;71:614-624

74. Nishimura K, Semba S, Aoyagi K, Sasaki H, Yokozaki H. Mesenchymal stem cells provide an advantageous tumor microenvironment for the restoration of cancer stem cells. Pathobiology 2012;79:290-306

75. Corcoran KE, Trzaska KA, Fernandes H, Bryan $M$, Taborga M, Srinivas V, Packman K, Patel PS, Rameshwar P. Mesenchymal stem cells in early entry of breast cancer into bone marrow. PLoS One 2008;3:e2563

76. Xu WT, Bian ZY, Fan QM, Li G, Tang TT. Human mesenchymal stem cells (hMSCs) target osteosarcoma and promote its growth and pulmonary metastasis. Cancer Lett 2009;281:32-41

77. Karnoub AE, Dash AB, Vo AP, Sullivan A, Brooks MW, Bell GW, Richardson AL, Polyak K, Tubo R, Weinberg RA. Mesenchymal stem cells within tumour stroma promote breast cancer metastasis. Nature 2007;449:557-563

78. Tsukamoto S, Honoki K, Fujii H, Tohma Y, Kido A, Mori T, Tsujiuchi T, Tanaka Y. Mesenchymal stem cells promote tumor engraftment and metastatic colonization in rat osteosarcoma model. Int J Oncol 2012;40:163-169

79. Djouad F, Plence P, Bony C, Tropel P, Apparailly F, Sany J, Noël D, Jorgensen C. Immunosuppressive effect of mesenchymal stem cells favors tumor growth in allogeneic animals. Blood 2003;102:3837-3844

80. Lee HY, Hong IS. Double-edged sword of mesenchymal stem cells: cancer-promoting versus therapeutic potential. Cancer Sci 2017;108:1939-1946

81. Rhodes LV, Antoon JW, Muir SE, Elliott S, Beckman BS, Burow ME. Effects of human mesenchymal stem cells on ER-positive human breast carcinoma cells mediated through ER-SDF-1/CXCR4 crosstalk. Mol Cancer 2010;9:
295

82. Halpern JL, Kilbarger A, Lynch CC. Mesenchymal stem cells promote mammary cancer cell migration in vitro via the CXCR2 receptor. Cancer Lett 2011;308:91-99

83. Tsai KS, Yang SH, Lei YP, Tsai CC, Chen HW, Hsu CY, Chen LL, Wang HW, Miller SA, Chiou SH, Hung MC, Hung SC. Mesenchymal stem cells promote formation of colorectal tumors in mice. Gastroenterology 2011;141: 1046-1056

84. Melzer C, Yang Y, Hass R. Interaction of MSC with tumor cells. Cell Commun Signal 2016;14:20

85. Norozi F, Ahmadzadeh A, Shahrabi S, Vosoughi T, Saki $\mathrm{N}$. Mesenchymal stem cells as a double-edged sword in suppression or progression of solid tumor cells. Tumour Biol 2016;37:11679-11689

86. Raposo G, Stoorvogel W. Extracellular vesicles: exosomes, microvesicles, and friends. J Cell Biol 2013;200:373-383

87. Braicu C, Tomuleasa C, Monroig P, Cucuianu A, Berindan-Neagoe I, Calin GA. Exosomes as divine messengers: are they the Hermes of modern molecular oncology? Cell Death Differ 2015;22:34-45

88. Zhang L, Hao C, Yao S, Tang R, Guo W, Cong H, Li J, Bao L, Wang D, Li Y, Yu X, Duan S, Yao W. Exosomal miRNA profiling to identify nanoparticle phagocytic mechanisms. Small 2018;14:e1704008

89. Zarredar H, Ansarin K, Baradaran B, Shekari N, Eyvazi S, Safari F, Farajnia S. Critical microRNAs in lung cancer: recent advances and potential applications. Anticancer Agents Med Chem 2018;18:1991-2005

90. Zafari V, Shanehbandi D, Bornehdeli S, Sadeghzadeh M, Zarredar H, Asadi M, Sharifi A. MicroRNA profiling in non-small cell lung cancer and its implications for the disease pathogenesis. Middle East J Cancer 2021;12:79-85

91. Neviani P, Fabbri M. Exosomic microRNAs in the tumor microenvironment. Front Med (Lausanne) 2015;2:47

92. Ratajczak J, Miekus K, Kucia M, Zhang J, Reca R, Dvorak P, Ratajczak MZ. Embryonic stem cell-derived microvesicles reprogram hematopoietic progenitors: evidence for horizontal transfer of mRNA and protein delivery. Leukemia 2006;20:847-856

93. Burrello J, Monticone S, Gai C, Gomez Y, Kholia S, Camussi G. Stem cell-derived extracellular vesicles and immune-modulation. Front Cell Dev Biol 2016;4:83

94. Pinto A, Marangon I, Méreaux J, Nicolás-Boluda A, Lavieu G, Wilhelm C, Sarda-Mantel L, Silva AKA, Pocard $M$, Gazeau F. Immune reprogramming precision photodynamic therapy of peritoneal metastasis by scalable stem-cell-derived extracellular vesicles. ACS Nano 2021; 15:3251-3263

95. Gowen A, Shahjin F, Chand S, Odegaard KE, Yelamanchili SV. Mesenchymal stem cell-derived extracellular vesicles: challenges in clinical applications. Front Cell Dev Biol 2020;8:149

96. Zhou Y, Xu H, Xu W, Wang B, Wu H, Tao Y, Zhang B, Wang M, Mao F, Yan Y, Gao S, Gu H, Zhu W, Qian $\mathrm{H}$. Exosomes released by human umbilical cord mesen- 
chymal stem cells protect against cisplatin-induced renal oxidative stress and apoptosis in vivo and in vitro. Stem Cell Res Ther 2013;4:34

97. Zhu W, Huang L, Li Y, Zhang X, Gu J, Yan Y, Xu X, Wang $\mathrm{M}$, Qian $\mathrm{H}, \mathrm{Xu}$ W. Exosomes derived from human bone marrow mesenchymal stem cells promote tumor growth in vivo. Cancer Lett 2012;315:28-37

98. Bruno S, Collino F, Deregibus MC, Grange C, Tetta C, Camussi G. Microvesicles derived from human bone marrow mesenchymal stem cells inhibit tumor growth. Stem Cells Dev 2013;22:758-771

99. Lee JK, Park SR, Jung BK, Jeon YK, Lee YS, Kim MK, Kim YG, Jang JY, Kim CW. Exosomes derived from mesenchymal stem cells suppress angiogenesis by down-regulating VEGF expression in breast cancer cells. PLoS One 2013;8:e84256

100. Hua Z, Lv Q, Ye W, Wong CK, Cai G, Gu D, Ji Y, Zhao C, Wang J, Yang BB, Zhang Y. MiRNA-directed regulation of VEGF and other angiogenic factors under hypoxia. PLoS One 2006;1:e116

101. Karimi L, Zeinali T, Hosseinahli N, Mansoori B, Mohammadi A, Yousefi M, Asadi M, Sadreddini S, Baradaran B, Shanehbandi D. miRNA-143 replacement therapy harnesses the proliferation and migration of colorectal cancer cells in vitro. J Cell Physiol 2019;234:2135921368

102. Shimbo K, Miyaki S, Ishitobi H, Kato Y, Kubo T, Shimose $\mathrm{S}$, Ochi M. Exosome-formed synthetic microRNA-143 is transferred to osteosarcoma cells and inhibits their migration. Biochem Biophys Res Commun 2014;445:381387

103. Maestroni GJ, Hertens E, Galli P. Factor(s) from nonmacrophage bone marrow stromal cells inhibit Lewis lung carcinoma and B16 melanoma growth in mice. Cell Mol Life Sci 1999;55:663-667

104. Nakamura K, Ito Y, Kawano Y, Kurozumi K, Kobune M, Tsuda H, Bizen A, Honmou O, Niitsu Y, Hamada H. Antitumor effect of genetically engineered mesenchymal stem cells in a rat glioma model. Gene Ther 2004;11: 1155-1164

105. Qiao C, Xu W, Zhu W, Hu J, Qian H, Yin Q, Jiang R, Yan Y, Mao F, Yang H, Wang X, Chen Y. Human mesenchymal stem cells isolated from the umbilical cord. Cell Biol Int 2008;32:8-15

106. Khakoo AY, Pati S, Anderson SA, Reid W, Elshal MF, Rovira II, Nguyen AT, Malide D, Combs CA, Hall G, Zhang J, Raffeld M, Rogers TB, Stetler-Stevenson W, Frank JA, Reitz M, Finkel T. Human mesenchymal stem cells exert potent antitumorigenic effects in a model of Kaposi's sarcoma. J Exp Med 2006;203:1235-1247

107. Gondi CS, Veeravalli KK, Gorantla B, Dinh DH, Fassett D, Klopfenstein JD, Gujrati M, Rao JS. Human umbilical cord blood stem cells show PDGF-D-dependent glioma cell tropism in vitro and in vivo. Neuro Oncol 2010;12: 453-465

108. Dasari VR, Velpula KK, Kaur K, Fassett D, Klopfenstein
JD, Dinh DH, Gujrati M, Rao JS. Cord blood stem cell-mediated induction of apoptosis in glioma downregulates X-linked inhibitor of apoptosis protein (XIAP). PLoS One 2010;5:e11813

109. Akimoto K, Kimura K, Nagano M, Takano S, To'a Salazar G, Yamashita T, Ohneda O. Umbilical cord blood-derived mesenchymal stem cells inhibit, but adipose tissue-derived mesenchymal stem cells promote, glioblastoma multiforme proliferation. Stem Cells Dev 2013;22:1370-1386

110. Wilting J, Christ B. Embryonic angiogenesis: a review. Naturwissenschaften 1996;83:153-164

111. Risau W, Flamme I. Vasculogenesis. Annu Rev Cell Dev Biol 1995;11:73-91

112. Tarhriz V, Bandehpour M, Dastmalchi S, Ouladsahebmadarek E, Zarredar H, Eyvazi S. Overview of CD24 as a new molecular marker in ovarian cancer. J Cell Physiol 2019;234:2134 2142

113. Folkman J. Tumor angiogenesis: therapeutic implications. N Engl J Med 1971;285:1182-1186

114. Ribatti D. The involvement of endothelial progenitor cells in tumor angiogenesis. J Cell Mol Med 2004;8:294-300

115. Ferrara N, Henzel WJ. Pituitary follicular cells secrete a novel heparin-binding growth factor specific for vascular endothelial cells. Biochem Biophys Res Commun 1989; 161:851-858

116. Khoury CC, Ziyadeh FN. Angiogenic factors. Contrib Nephrol 2011;170:83-92

117. Taraboletti G, Rusnati M, Ragona L, Colombo G. Targeting tumor angiogenesis with TSP-1-based compounds: rational design of antiangiogenic mimetics of endogenous inhibitors. Oncotarget 2010;1:662-673

118. Algire GH, Chalkley HW, Legallais FY, Park HD. Vasculae reactions of normal and malignant tissues in vivo. I. vascular reactions of mice to wounds and to normal and neoplastic transplants. J Natl Cancer Inst 1945; 6:73-85

119. Zarredar H, Ansarin K, Baradaran B, Ahdi Khosroshahi $\mathrm{S}$, Farajnia S. Potential molecular targets in the treatment of lung cancer using siRNA technology. Cancer Invest 2018;36:37-58

120. Ferrara N, Gerber HP, LeCouter J. The biology of VEGF and its receptors. Nat Med 2003;9:669-676

121. Wang GL, Semenza GL. Purification and characterization of hypoxia-inducible factor 1. J Biol Chem 1995;270:12301237

122. Brahimi-Horn C, Pouysségur J. The role of the hypoxia-inducible factor in tumor metabolism growth and invasion. Bull Cancer 2006;93:E73-E80

123. Ellis LM, Hicklin DJ. VEGF-targeted therapy: mechanisms of anti-tumour activity. Nat Rev Cancer 2008;8:579591

124. Petrova TV, Bono P, Holnthoner W, Chesnes J, Pytowski B, Sihto H, Laakkonen P, Heikkilä P, Joensuu H, Alitalo $\mathrm{K}$. VEGFR-3 expression is restricted to blood and lymphatic vessels in solid tumors. Cancer Cell 2008;13:554556 
125. Zarredar H, Pashapour S, Ansarin K, Khalili M, Baghban R, Farajnia S. Combination therapy with KRAS siRNA and EGFR inhibitor AZD8931 suppresses lung cancer cell growth in vitro. J Cell Physiol 2019;234:1560-1566

126. Kim KJ, Li B, Winer J, Armanini M, Gillett N, Phillips HS, Ferrara N. Inhibition of vascular endothelial growth factor-induced angiogenesis suppresses tumour growth in vivo. Nature 1993;362:841-844

127. Presta LG, Chen H, O'Connor SJ, Chisholm V, Meng YG, Krummen L, Winkler M, Ferrara N. Humanization of an anti-vascular endothelial growth factor monoclonal antibody for the therapy of solid tumors and other disorders. Cancer Res 1997;57:4593-4599

128. Hurwitz H, Fehrenbacher L, Novotny W, Cartwright T, Hainsworth J, Heim W, Berlin J, Baron A, Griffing S, Holmgren E, Ferrara N, Fyfe G, Rogers B, Ross R, Kabbinavar F. Bevacizumab plus irinotecan, fluorouracil, and leucovorin for metastatic colorectal cancer. $\mathrm{N}$ Engl J Med 2004;350:2335-2342

129. Asadi M, Shanehbandi D, Zarintan A, Pedram N, Baradaran B, Zafari V, Shirmohamadi M, Hashemzadeh S. TP53 gene Pro72Arg (rs1042522) single nucleotide polymorphism as not a risk factor for colorectal cancer in the Iranian Azari Population. Asian Pac J Cancer Prev 2017;18:3423-3427

130. Sandler A, Gray R, Perry MC, Brahmer J, Schiller JH, Dowlati A, Lilenbaum R, Johnson DH. Paclitaxel-carboplatin alone or with bevacizumab for non-small-cell lung cancer. N Engl J Med 2006;355:2542-2550

131. Miller K, Wang M, Gralow J, Dickler M, Cobleigh M, Perez EA, Shenkier T, Cella D, Davidson NE. Paclitaxel plus bevacizumab versus paclitaxel alone for metastatic breast cancer. N Engl J Med 2007;357:2666-2676

132. Holash J, Davis S, Papadopoulos N, Croll SD, Ho L, Russell M, Boland P, Leidich R, Hylton D, Burova E, Ioffe E, Huang T, Radziejewski C, Bailey K, Fandl JP, Daly T, Wiegand SJ, Yancopoulos GD, Rudge JS. VEGF-Trap: a VEGF blocker with potent antitumor effects. Proc Natl Acad Sci U S A 2002;99:11393-11398

133. Ellis LM, Hicklin DJ. Pathways mediating resistance to vascular endothelial growth factor-targeted therapy. Clin Cancer Res 2008;14:6371-6375

134. Kerbel RS. Tumor angiogenesis. N Engl J Med 2008;358: 2039-2049

135. Jiang F, Albert DH, Luo Y, Tapang P, Zhang K, Davidsen SK, Fox GB, Lesniewski R, McKeegan EM. ABT-869, a multitargeted receptor tyrosine kinase inhibitor, reduces tumor microvascularity and improves vascular wall integrity in preclinical tumor models. J Pharmacol Exp Ther 2011;338:134-142

136. Tan EH, Goss GD, Salgia R, Besse B, Gandara DR, Hanna $\mathrm{NH}$, Yang JC, Thertulien R, Wertheim M, Mazieres J, Hensing T, Lee C, Gupta N, Pradhan R, Qian J, Qin Q, Scappaticci FA, Ricker JL, Carlson DM, Soo RA. Phase 2 trial of linifanib (ABT-869) in patients with advanced non-small cell lung cancer. J Thorac Oncol 2011;6:1418-
1425

137. You WK, Sennino B, Williamson CW, Falcón B, Hashizume H, Yao LC, Aftab DT, McDonald DM. VEGF and c-Met blockade amplify angiogenesis inhibition in pancreatic islet cancer. Cancer Res 2011;71:4758-4768

138. Ho TH, Jonasch E. Axitinib in the treatment of metastatic renal cell carcinoma. Future Oncol 2011;7:1247-1253

139. Eskens FA, de Jonge MJ, Bhargava P, Isoe T, Cotreau MM, Esteves B, Hayashi K, Burger $\mathrm{H}$, Thomeer M, van Doorn L, Verweij J. Biologic and clinical activity of tivozanib (AV-951, KRN-951), a selective inhibitor of VEGF receptor-1, -2 , and -3 tyrosine kinases, in a 4-week-on, 2-week-off schedule in patients with advanced solid tumors. Clin Cancer Res 2011;17:7156-7163

140. Langmuir PB, Yver A. Vandetanib for the treatment of thyroid cancer. Clin Pharmacol Ther 2012;91:71-80

141. O'Farrell AM, Abrams TJ, Yuen HA, Ngai TJ, Louie SG, Yee KW, Wong LM, Hong W, Lee LB, Town A, Smolich BD, Manning WC, Murray LJ, Heinrich MC, Cherrington JM. SU11248 is a novel FLT3 tyrosine kinase inhibitor with potent activity in vitro and in vivo. Blood 2003;101: 3597-3605

142. Sleijfer S, Ray-Coquard I, Papai Z, Le Cesne A, Scurr M, Schöffski P, Collin F, Pandite L, Marreaud S, De Brauwer A, van Glabbeke M, Verweij J, Blay JY. Pazopanib, a multikinase angiogenesis inhibitor, in patients with relapsed or refractory advanced soft tissue sarcoma: a phase II study from the European organisation for research and treatment of cancer-soft tissue and bone sarcoma group (EORTC study 62043). J Clin Oncol 2009;27:3126-3132

143. Richly H, Henning BF, Kupsch P, Passarge K, Grubert M, Hilger RA, Christensen O, Brendel E, Schwartz B, Ludwig M, Flashar C, Voigtmann R, Scheulen ME, Seeber S, Strumberg D. Results of a Phase I trial of sorafenib (BAY 43-9006) in combination with doxorubicin in patients with refractory solid tumors. Ann Oncol 2006;17: 866-873

144. Jain RK. Normalization of tumor vasculature: an emerging concept in antiangiogenic therapy. Science 2005;307: $58-62$

145. Cooney MM, van Heeckeren W, Bhakta S, Ortiz J, Remick SC. Drug insight: vascular disrupting agents and angiogenesis--novel approaches for drug delivery. Nat Clin Pract Oncol 2006;3:682-692

146. McKeage MJ, Von Pawel J, Reck M, Jameson MB, Rosenthal MA, Sullivan R, Gibbs D, Mainwaring PN, Serke M, Lafitte JJ, Chouaid C, Freitag L, Quoix E. Randomised phase II study of ASA404 combined with carboplatin and paclitaxel in previously untreated advanced non-small cell lung cancer. Br J Cancer 2008;99:2006-2012

147. Ghaedi M, Soleimani M, Taghvaie NM, Sheikhfatollahi M, Azadmanesh K, Lotfi AS, Wu J. Mesenchymal stem cells as vehicles for targeted delivery of anti-angiogenic protein to solid tumors. J Gene Med 2011;13:171-180

148. Toi M, Hoshina S, Takayanagi T, Tominaga $T$. Association of vascular endothelial growth factor ex- 
pression with tumor angiogenesis and with early relapse in primary breast cancer. Jpn J Cancer Res 1994;85: 1045-1049

149. Folkman J, Watson K, Ingber D, Hanahan D. Induction of angiogenesis during the transition from hyperplasia to neoplasia. Nature 1989;339:58-61

150. Zheng L, Zhang D, Chen X, Yang L, Wei Y, Zhao X. Antitumor activities of human placenta-derived mesenchymal stem cells expressing endostatin on ovarian cancer. PLoS One 2012;7:e39119

151. Batchelor TT, Sorensen AG, di Tomaso E, Zhang WT, Duda DG, Cohen KS, Kozak KR, Cahill DP, Chen PJ, Zhu M, Ancukiewicz M, Mrugala MM, Plotkin S, Drappatz J, Louis DN, Ivy P, Scadden DT, Benner T, Loeffler JS, Wen PY, Jain RK. AZD2171, a pan-VEGF receptor tyrosine kinase inhibitor, normalizes tumor vasculature and alleviates edema in glioblastoma patients. Cancer Cell 2007;11:83-95

152. Kadambi A, Mouta Carreira C, Yun CO, Padera TP, Dolmans DE, Carmeliet P, Fukumura D, Jain RK. Vascular endothelial growth factor (VEGF)-C differentially affects tumor vascular function and leukocyte recruitment: role of VEGF-receptor 2 and host VEGF-A. Cancer Res 2001;61:2404-2408

153. Tong RT, Boucher Y, Kozin SV, Winkler F, Hicklin DJ, Jain RK. Vascular normalization by vascular endothelial growth factor receptor 2 blockade induces a pressure gradient across the vasculature and improves drug penetration in tumors. Cancer Res 2004;64:3731-3736

154. Bexell D, Gunnarsson S, Tormin A, Darabi A, Gisselsson D, Roybon L, Scheding S, Bengzon J. Bone marrow multipotent mesenchymal stroma cells act as pericyte-like migratory vehicles in experimental gliomas. Mol Ther 2009; $17: 183-190$

155. Mirzaei H, Salehi H, Oskuee RK, Mohammadpour A, Mirzaei HR, Sharifi MR, Salarinia R, Darani HY, Mokhtari M, Masoudifar A, Sahebkar A, Salehi R, Jaafari $M R$. The therapeutic potential of human adipose-derived mesenchymal stem cells producing CXCL10 in a mouse melanoma lung metastasis model. Cancer Lett 2018;419: 30-39

156. Hyder SM, Stancel GM. Regulation of angiogenic growth factors in the female reproductive tract by estrogens and progestins. Mol Endocrinol 1999;13:806-811

157. Zygmunt M, Herr F, Münstedt K, Lang U, Liang OD. Angiogenesis and vasculogenesis in pregnancy. Eur J Obstet Gynecol Reprod Biol 2003;110 Suppl 1:S10-S18

158. Jensen EV, Jordan VC. The estrogen receptor: a model for molecular medicine. Clin Cancer Res 2003;9:1980-1989

159. Horwitz KB. The central role of progesterone receptors and progestational agents in the management and treatment of breast cancer. Semin Oncol 1988;15(2 Suppl 1):1419

160. Kuiper GG, Carlsson B, Grandien K, Enmark E, Häggblad J, Nilsson S, Gustafsson JA. Comparison of the ligand binding specificity and transcript tissue distribution of es- trogen receptors alpha and beta. Endocrinology 1997;138: 863-870

161. Chang WY, Prins GS. Estrogen receptor-beta: implications for the prostate gland. Prostate 1999;40:115-124

162. Makar AP. Hormone therapy in epithelial ovarian cancer. Endocr Relat Cancer 2000;7:85-93

163. Rossouw JE, Anderson GL, Prentice RL, LaCroix AZ, Kooperberg C, Stefanick ML, Jackson RD, Beresford SA, Howard BV, Johnson KC, Kotchen JM, Ockene J; Writing Group for the Women's Health Initiative Investigators. Risks and benefits of estrogen plus progestin in healthy postmenopausal women: principal results From the Women's Health Initiative randomized controlled trial. JAMA 2002;288:321-333

164. Vázquez F, Rodríguez-Manzaneque JC, Lydon JP, Edwards DP, O'Malley BW, Iruela-Arispe ML. Progesterone regulates proliferation of endothelial cells. J Biol Chem 1999; 274:2185-2192

165. Iruela-Arispe ML, Rodriguez-Manzaneque JC, Abu-Jawdeh G. Endometrial endothelial cells express estrogen and progesterone receptors and exhibit a tissue specific response to angiogenic growth factors. Microcirculation 1999;6:127140

166. Reynolds LP, Redmer DA. Growth and development of the corpus luteum. J Reprod Fertil Suppl 1999;54:181-191

167. Chuderland D, Ben-Ami I, Kaplan-Kraicer R, Grossman H, Komsky A, Satchi-Fainaro R, Eldar-Boock A, Ron-El $\mathrm{R}$, Shalgi R. Hormonal regulation of pigment epithelium-derived factor (PEDF) in granulosa cells. Mol Hum Reprod 2013;19:72-81

168. Shah K. Mesenchymal stem cells engineered for cancer therapy. Adv Drug Deliv Rev 2012;64:739-748

169. Levy O, Zhao W, Mortensen LJ, Leblanc S, Tsang K, Fu M, Phillips JA, Sagar V, Anandakumaran P, Ngai J, Cui $\mathrm{CH}$, Eimon P, Angel M, Lin CP, Yanik MF, Karp JM. mRNA-engineered mesenchymal stem cells for targeted delivery of interleukin-10 to sites of inflammation. Blood 2013;122:e23-e32

170. Vartanian A, Karshieva S, Dombrovsky V, Belyavsky A. Melanoma educates mesenchymal stromal cells towards vasculogenic mimicry. Oncol Lett 2016;11:4264-4268

171. Lalu MM, McIntyre L, Pugliese C, Fergusson D, Winston BW, Marshall JC, Granton J, Stewart DJ. Safety of cell therapy with mesenchymal stromal cells (SafeCell): a systematic review and meta-analysis of clinical trials. PLoS One 2012;7:e47559

172. Hong S, Tan M, Wang S, Luo S, Chen Y, Zhang L. Efficacy and safety of angiogenesis inhibitors in advanced non-small cell lung cancer: a systematic review and meta-analysis. J Cancer Res Clin Oncol 2015;141:909-921

173. Li X, Zhu S, Hong C, Cai H. Angiogenesis inhibitors for patients with ovarian cancer: a meta-analysis of 12 randomized controlled trials. Curr Med Res Opin 2016;32:555-562

174. Cascone T, Herynk MH, Xu L, Du Z, Kadara H, Nilsson MB, Oborn CJ, Park YY, Erez B, Jacoby JJ, Lee JS, Lin 
HY, Ciardiello F, Herbst RS, Langley RR, Heymach JV. Upregulated stromal EGFR and vascular remodeling in mouse xenograft models of angiogenesis inhibitor-resistant human lung adenocarcinoma. J Clin Invest 2011;121:13131328

175. Semenza GL. Oxygen sensing, hypoxia-inducible factors, and disease pathophysiology. Annu Rev Pathol 2014;9:47-

\section{1}

176. Pàez-Ribes M, Allen E, Hudock J, Takeda T, Okuyama $H$, Viñals F, Inoue $M$, Bergers $G$, Hanahan D, Casanovas O. Antiangiogenic therapy elicits malignant progression of tumors to increased local invasion and distant metastasis. Cancer Cell 2009;15:220-231 